Jurnal Ekonomi Pembangunan

Volume 12, Nomor 1, Juni 2011, hlm.15-27

\title{
MODEL PEMBERDAYAAN MASYARAKAT
}

\author{
Kesi Widjajanti \\ Fakultas Ekonomi Universitas Semarang \\ Jalan Soekarno-Hatta Semarang 50196 Indonesia Telepon +62-024-6702757
}

Diterima 2 Desember 2010/Disetujui 15 April 2011

\begin{abstract}
The issue in this research is how to improve society ability through process human and physical capital. The relation between capital and ability improvement will be examined in this research by placing process empowerment as mediating variable to explain the activities involved. The data used in this study are primary and secondary data. The primary data was collected using survey method technique through questionnaire. Furthermore statistical analysis was used Structural Equation Modeling (SEM) of Smart Partial Least Square. This research has found two ways as path patterns directed to the increasing of society ability, which are (1) pattern consist of "two creating stage" to society ability, and (2) These pattern show that to improve society ability need "three stage" of process activity. The correlation is while the empowerment process increases higher, it will impulse the creating of society ability. The implementation of this research's result, stated that if the empowerment wants to develop human capital, it will be better if the empowerment is supported by apply the developing ability of subject empowerment.
\end{abstract}

Keywords: physical capital, human capital, ability society, empowerment process

\begin{abstract}
Abstrak: Masalah penelitian adalah bagaimana meningkatkan keberdayaan masyarakat melalui proses modal manusia dan modal fisik. Hubungan antara modal dan perbaikan keberdayaan akan diuji dengan meletakkan proses pemberdayaan sebagai variabel mediasi untuk menjelaskan aktivitas-aktivitas yang terkait. Data yang digunakan adalah data primer dan sekunder, data primer dikumpulkan dengan menggunakan metode survei melalui kuesioner. Selanjutnya, analisis statistik yang digunakan adalah Structural Equation Modeling (SEM)Smart Partial Least Square. Temuan penelitian menunjukkan ada dua pola cara yang mengarah pada peningkatan keberdayaan masyarakat, dimana (1) pola yang terdiri dari dua tahapan untuk keberdayaan, dan (2) pola yang menunjukkan bahwa untuk meningkatkan keberdayaan diperlukan tiga tahapan proses aktivitas. Terdapat korelasi dimana semakin tinggi proses pemberdayaan akan dapat menciptakan keberdayaan masyarakat. Implementasi dari hasil penelitian ini adalah bahwa pemberdayaan menginginkan pengembangan modal manusia, dan akan lebih baik lagi jika pemberdayaan didukung oleh pengembangan kemampuan pelaku pemberdayaan.
\end{abstract}

Kata kunci: modal fisik, modal manusia, keberdayaan masyarakat, proses pemberdayaan

\section{PENDAHULUAN}

Tanggung jawab utama dalam program pembangunan adalah masyarakat berdaya atau memiliki daya, kekuatan atau kemampuan. Kekuatan yang dimaksud dapat dilihat dari aspek fisik dan material, ekonomi, kelembagaan, kerja- sama, kekuatan intelektual dan komitmen bersama dalam menerapkan prinsip-prinsip pemberdayaan. Kemampuan berdaya mempunyai arti yang sama dengan kemandirian masyarakat. Terkait dengan program pembangunan, bahwa tujuan yang ingin dicapai adalah untuk membentuk individu dan masyarakat menjadi mandiri. Kemandirian tersebut 
meliputi kemandirian berpikir, bertindak dan mengendalikan apa yang mereka lakukan.

Kemandirian masyarakat merupakan suatu kondisi yang dialami oleh masyarakat yang ditandai dengan kemampuan memikirkan, memutuskan serta melakukan sesuatu yang dipandang tepat demi mencapai pemecahan masalah-masalah yang dihadapi dengan mempergunakan daya kemampuan yang dimiliki. Daya kemampuan yang dimaksud adalah kemampuan kognitif, konatif, psikomotorik dan afektif serta sumber daya lainnya yang bersifat fisik/ material. Kemandirian masyarakat dapat dicapai tentu memerlukan sebuah proses belajar. Masyarakat yang mengikuti proses belajar yang baik, secara bertahap akan memperoleh daya, kekuatan atau kemampuan yang bermanfaat dalam proses pengambilan keputusan secara mandiri. Berkaitan dengan hal ini, Sumodiningrat (2000) menjelaskan bahwa keberdayaan masyarakat yang ditandai adanya kemandiriannya dapat dicapai melalui proses pemberdayaan masyarakat.

Keberdayaan masyarakat dapat diwujudkan melalui partisipasi aktif masyarakat yang difasilitasi dengan adanya pelaku pemberdayaan. Sasaran utama pemberdayaan masyarakat adalah mereka yang lemah dan tidak memiliki daya, kekuatan atau kemampuan mengakses sumberdaya produktif atau masyarakat yang terpinggirkan dalam pembangunan. Tujuan akhir dari proses pemberdayaan masyarakat adalah untuk memandirikan warga masyarakat agar dapat meningkatkan taraf hidup keluarga dan mengoptimalkan sumberdaya yang dimilikinya. Secara sosial, masyarakat sekitar kawasan hutan lindung sampai saat ini tetap teridentifikasi sebagai masyarakat marginal (terpinggirkan) dan tidak memiliki daya, kekuatan, dan kemampuan yang dapat diandalkan serta tidak memiliki modal yang memadai untuk bersaing dengan masyarakat kapitalis atau masyarakat pengusaha yang secara sosial dan politik memiliki daya, kekuatan, dan kemampuan yang memadai. Ketidakberdayaan masyarakat secara sosial dan ekonomi menjadi salah satu ganjalan bagi masyarakat untuk berdiri sama tinggi dan duduk sama rendah dengan sesama saudaranya yang telah berhasil. Kondisi inilah yang perlu dipahami dan dijadi- kan salah satu pertimbangan dalam pengambilan kebijakan dan perencanaan penyusunan program, agar setiap kebijakan dan program tentang pengaturan pengelolaan hutan yang diambil tetap memperhatikan kondisi sosial budaya dan ekonomi masyarakat sekitar kawasan hutan lindung.

Paradigma perencanaan pengelolaan hutan dan pemberdayaan masyarakat yang sentralistik dimana program dirancang dari atas tanpa melibatkan masyarakat, harus diubah kearah peningkatan partisipasi masyarakat lokal secara optimal. Pemberdayaan dapat diartikan sebagai suatu pelimpahan atau pemberian kekuatan (power) yang akan menghasilkan hierarki kekuatan dan ketiadaan kekuatan, seperti yang dikemukakan Simon (1993) bahwa pemberdayaan merupakan suatu aktvitas refleksi, suatu proses yang mampu diinisiasikan dan dipertahankan hanya oleh agen atau subyek yang mencari kekuatan atau penentuan diri sendiri (self-determination). Sulistiyani (2004) menjelaskan lebih rinci bahwa secara etimologis pemberdayaan berasal dari kata dasar "daya" yang berarti kekuatan atau kemampuan. Bertolak dari pengertian tersebut, maka pemberdayaan dimaknai sebagai proses untuk memperoleh daya, kekuatan atau kemampuan, dan atau proses pemberian daya, kekuatan atau kemampuan dari pihak yang memiliki daya kepada pihak yang kurang atau belum berdaya. Berdasarkan beberapa pengertian pemberdayaan yang dikemukakan tersebut, maka dapat disimpulkan bahwa pada hakekatnya pemberdayaan adalah suatu proses dan upaya untuk memperoleh atau memberikan daya, kekuatan atau kemampuan kepada individu dan masyarakat lemah agar dapat mengidentifikasi, menganalisis, menetapkan kebutuhan dan potensi serta masalah yang dihadapi dan sekaligus memilih alternatif pemecahannya dengan mengoptimalkan sumber daya dan potensi yang dimiliki secara mandiri. Pranarka dan Vidhyandika (1996) menjelaskan bahwa proses pemberdayaan mengandung dua kecenderungan. Pertama, proses pemberdayaan yang menekankan pada proses memberikan atau mengalihkan sebagian kekuatan, kekuasaan atau kemampuan kepada masyarakat agar individu lebih berdaya

Pada era reformasi dan desentralisasi saat 
ini, tuntutan terhadap pelaku pemberdayaan yang memiliki kemampuan yang memadai semakin menguat. Pelaku pemberdayaan tidak hanya dituntut untuk memperkaya pengetahuannya, melainkan mereka dituntut meningkatkan keterampilannya dalam mendesain program pemberdayaan. Lantas muncul pertanyaan, kemampuan seperti apa yang harus dimiliki oleh pelaku pemberdayaan?. Huseini (1999) menjelaskan bahwa modal manusia merupakan refleksi dari pendidikan, pengalaman, intuisi dan keahlian. Era globalisasi yang menuntut perhatian terhadap modal manusia semakin tinggi, terkait dengan perkembangan dalam ilmu ekonomi pembangunan dan sosiologi. Para ahli kedua bidang tersebut umumnya sepakat pada satu hal, yakni modal manusia berperan secara signifikan, bahkan lebih penting daripada faktor teknologi, dalam memacu pertumbuhan ekonomi. Modal manusia (human capital) tersebut tidak hanya menyangkut kuantitas tetapi juga kualitas. Lalu muncul pertanyaan, apa ukuran yang menentukan kualitas manusia?. Berdasarkan beberapa definisi modal manusia yang telah diuraikan, maka dapat disimpulkan bahwa modal manusia (human capital) adalah suatu aset yang berhubungan dengan intelektualitas dan kondisi seseorang yang diperoleh melalui pendidikan formal dan nonformal yang didukung oleh kesehatan jasmani dan rohani yang prima dan kemampuan melakukan hubungan/interaksi antarsesama secara baik, menguntungkan, dan berkelanjutan.

Penting juga diketahui bentuk transaksi yang dalam teori ekonomi dianggap sebagai nonekonomi karena tidak dapat secara langsung memaksimalkan keuntungan material. Padahal sebenarnya dalam setiap transaksi modal ekonomi selalu disertai oleh modal immaterial berbentuk modal budaya dan modal sosial. Syabra (2003) menjelaskan perbedaan antara modal ekonomi, modal budaya dan modal sosial, serta menggambarkan bagaimana ketiganya dapat dibedakan antara satu dengan yang lain dilihat dari tingkat kemudahannya untuk dikonversikan. Modal ekonomi dengan mudah dapat dikonversikan ke dalam bentuk uang dan dapat dilembagakan dalam bentuk hak kepemilikan. Dalam kondisi tertentu, modal budaya juga dapat dikonversikan menjadi modal yang memiliki nilai ekonomi, dan dapat dilembagakan, seperti kualifikasi pendidikan.

Berbagai penelitian menunjukkan bahwa modal sosial (social capital) merupakan fasilitator penting dalam pembangunan ekonomi. Modal sosial yang dibentuk berdasarkan kegiatan ekonomi dan sosial di masa lalu dipandang sebagai faktor yang dapat meningkatkan pembangunan ekonomi dan jika digunakan secara tepat mampu memperkuat efektivitas pembangunan (Suharto dan Yuliani, 2005). Berdasarkan beberapa penjelasan tersebut, maka dapat disimpulkan bahwa modal sosial adalah suatu norma atau nilai yang telah dipahami bersama oleh masyarakat yang dapat memperkuat jaringan sosial/kerja yang positif, terjalinnya kerjasama yang saling menguntungkan, menumbuhkan kepedulian dan solidaritas yang tinggi dan dapat mendorong tingkat kepercayaan antara sesama dalam rangka tercapainya tujuan bersama.

Penelitian ini mengkaji beberapa permasalahan yang berkaitan dengan faktor-faktor yang berpengaruh terhadap tingkat keberdayaan warga masyarakat dan merumuskan model pemberdayaan yang sesuai dengan kondisi lokasi. Dari uraian di atas dapat dirumuskan masalah penelitian yaitu "Bagaimana meningkatkan keberdayaan warga masyarakat, melalui proses pemberdayaan yang terwujud dari modal sosial, modal manusia, modal fisik dan kemampuan pelaku?. Tujuan penelitian adalah: (1) menganalisis faktor-faktor yang mempengaruhi modal sosial, (2) menganalisis faktor-faktor yang mempengaruhi proses pemberdayaan masyarakat, (3) menganalisis faktor-faktor yang mempengaruhi keberdayaan masyarakat, dan (4) merumuskan model pemberdayaan masyarakat.

\section{METODE PENELITIAN}

\section{Desain Penelitian}

Rancangan penelitian ini bersifat penelitian prediksi dan deskriptif yang melibatkan beberapa konsep. Analisis secara deskriptif diharapkan dapat memberikan penjelasan fenomena proses pemberdayaan masyarakat Limbangan, yang menggambarkan karakteristik masyarakat ter- 
sebut. Penelitian deskriptif penting dilakukan untuk mengarahkan berbagai kebijakan pemerintah yang berkaitan dengan aspek perilaku pelaku pemberdayaan dan aspek proses pemberdayaannya. Pada penggambaran variabel dalam model persamaan struktural, variabel kunci yang menjadi perhatian adalah variabel laten atau latent construct, yaitu konsep abstrak modal fisik, modal manusia, modal sosial, kemampuan pelaku, proses pemberdayaan masyarakat, dan keberdayaan warga masyarakat. Model struktural meliputi hubungan konstruk laten dan pengukurannya menggunakan indikator. Penelitian ini menggunakan konsep dan indikator beberapa peneliti terdahulu yaitu Pranarka dan Vidhyandika (1996), Kartasasmita (1995), Slamet (2003), dan Jamasy (2004).

\section{Definisi Operasional dan Pengukuran Variabel}

Modal fisik (physical capital). Modal fisik adalah fasilitas atau aset yang digunakan sebagai alat dan pendukung utama terselenggaranya suatu proses usaha atau aktivitas dalam rangka pencapaian tujuan seperti gedung, jalan, alat-alat, mesin, dan sebagainya. Modal fisik dalam penelitian ini diukur dengan menggunakan enam indikator yaitu: (a) sarana produksi pertanian, (b) sarana dan prasarana pendidikan, (c) sarana dan prasarana kesehatan, (d) sarana dan prasarana ekonomi, (e) sarana dan prasarana komunikasi, dan (f) sarana dan prasarana transportasi.

Modal Manusia (human capital). Modal manusia adalah aset yang berkaitan dengan kemampuan untuk melakukan suatu aktivitas tertentu. Modal manusia dalam penelitian ini diukur dengan menggunakan tiga indikator yaitu (a) tingkat pendidikan, (b) tingkat kesehatan dan (c) kemampuan membangun interaksi hubungan/asosiasi antarsesama.

Modal Sosial (social capital). Modal sosial adalah suatu norma atau nilai yang telah dipahami bersama oleh masyarakat yang dapat memperkuat jaringan sosial/kerja yang positif, dalam rangka tercapainya tujuan bersama untuk menciptakan nilai. Indikator yang digunakan dengan menggunakan lima pertanyaan yaitu adanya (a) jaringan sosial/kerja, (b) tingkat kepercayaan antara sesama, (c) ketaatan terhadap norma, (d) kepedulian terhadap sesama, dan (e) keterlibatan dalam aktivitas organisasi sosial

Kemampuan Pelaku Pemberdayaan. Kemampuan Pelaku Pemberdayaan adalah kemampuan yang dimiliki oleh pelaku pemberdayaan yang diharapkan dapat memberdayakan masyarakat. Kemampuan pelaku pemberdayaan diukur melalui tiga aspek perilaku yaitu: (a) pengetahuan/kognitif, (b) sikap/afektif,dan (c) keterampilan/psikomotorik.

Proses Pemberdayaan. Proses pemberdayaan adalah suatu siklus atau proses yang melibatkan masyarakat untuk bekerjasama dalam kelompok formal maupun nonformal untuk melakukan kajian masalah, merencanakan, melaksanakan, dan melakukan evaluasi terhadap program yang telah direncanakan bersama. Proses pemberdayaan diukur melalui (a) kualitas dan kuantitas keterlibatan masyarakat mulai dari kegiatan kajian atau analisis masalah, (b) perencanaan program, (c) pelaksanakan program, serta (d) keterlibatan dalam evaluasi secara berkelanjutan.

Keberdayaan Masyarakat. Keberdayaan masyarakat adalah dimilikinya daya, kekuatan atau kemampuan oleh masyarakat untuk mengidentifikasi potensi dan masalah serta dapat menentukan alternatif pemecahannya secara mandiri. Keberdayaan masyarakat diukur melalui tiga aspek (a) kemampuan dalam pengambilan keputusan, (b) kemandirian dan (c) kemampuan memanfaatkan usaha untuk masa depan.

\section{Sampel Penelitian}

Sampel penelitian adalah masyarakat yang dipilih yang dianggap berpatisipasi aktif dalam proses pemberdayaan dari sejumlah populasi masyarakat Desa Sumber Rahayu Kecamatan Limbangan di Kendal Jawa Tengah. Jumlah sampel dalam penelitian ini bejumlah 104 orang.

\section{Teknik Analisis Data}

Teknik analisis data dilakukan dengan model persamaan struktural dengan menggunakan Partial Least Square (PLS) dan SPSS dengan persamaan:

Modal Manusia $=\beta_{1} \mathrm{mf}+\ell_{1}$ 
Modal Sosial $=\beta_{1} \mathrm{mf}+\beta_{2} \mathrm{~mm}+\ell_{2}$

Pemberdayaan $=\beta_{1} \mathrm{~ms}+\beta_{2} \mathrm{mf}+\beta_{3} \mathrm{~mm}+$

$$
\beta_{4} \mathrm{kpp}+\ell_{3}
$$

Keberdayaan $=\beta_{1} \mathrm{pmb}+\beta_{2} \mathrm{~ms}+\beta_{3} \mathrm{~mm}+$

$$
\beta_{4} \mathrm{~mm}+\beta_{5} \mathrm{kpp}+\ell_{4}
$$

dimana mf adalah modal fisik, $\mathbf{m m}$ adalah modal manusia, ms adalah modal sosial, kpp adalah kemampuan pelaku pemberdayaan, pmb adalah pemberdayaan.

\section{HASIL DAN PEMBAHASAN}

Teknik analisis yang digunakan dalam pengujian empirik adalah model persamaan struktural menggunakan software Partial Least Square. Pengujian validitas dan reliabilitas data dilakukan dengan convergent dan discriminant validity. Convergent validity dapat dinilai dengan melihat reliabilitas indikator, composite reliability, dan average variance extracted. Sedangkan discriminant validity dengan cara membandingkan nilai akar dari Average Variance Extracted (AVE) setiap konstruk dengan korelasi antara konstruk dan konstruk lainnya.

Konstruk dinyatakan valid jika nilai akar dari average variance extract lebih besar dari korelasi antara konstruk dengan konstruk lainnya. Berdasarkan hasil analisis dapat disimpulkan bahwa semua konstruk dalam penelitian ini yaitu modal fisik, modal manusia, modal sosial, kemampuan pelaku pemberdayaan, proses pemberdayaan dan keberdayaan masyarakat mempunyai nilai akar AVE lebih besar dari korelasi antarkonstruk, yang berarti bahwa semua konstruk dalam model yang diestimasi memenuhi kriteria discriminant validity.

Jumlah indikator atau item pertanyaan yang digunakan dalam kuesioner sebanyak 24 pertanyaan. Secara lebih rinci, loading factor untuk masing-masing indikator dari konstruk modal fisik, modal manusia, modal sosial, kemampuan pelaku pemberdayaan, proses pemberdayaan, dan keberdayaan masyarakat dapat dilihat pada Gambar 1.

Gambar 1 menunjukkan model struktural

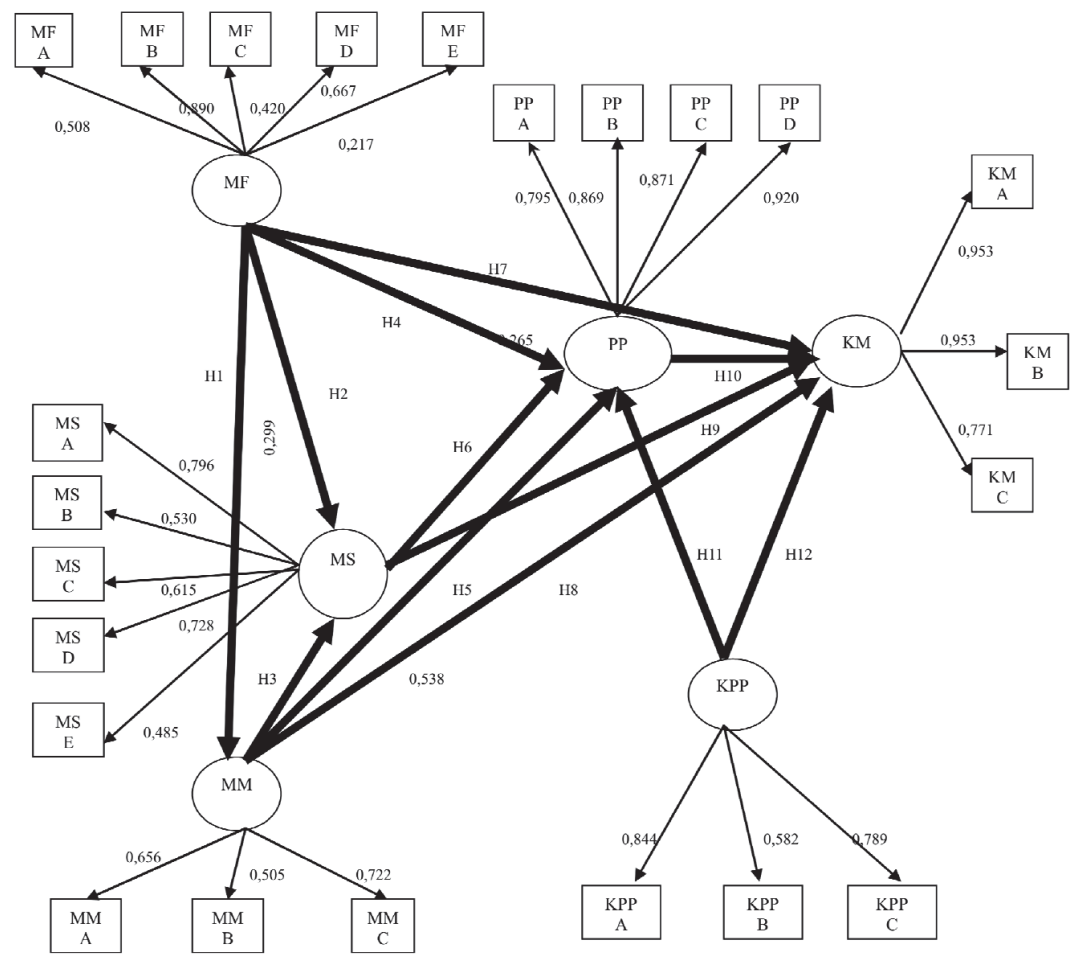

Gambar 1. Model Pemberdayaan Masyarakat Sebelum Dilakukan Pergujian Convergent Validity 


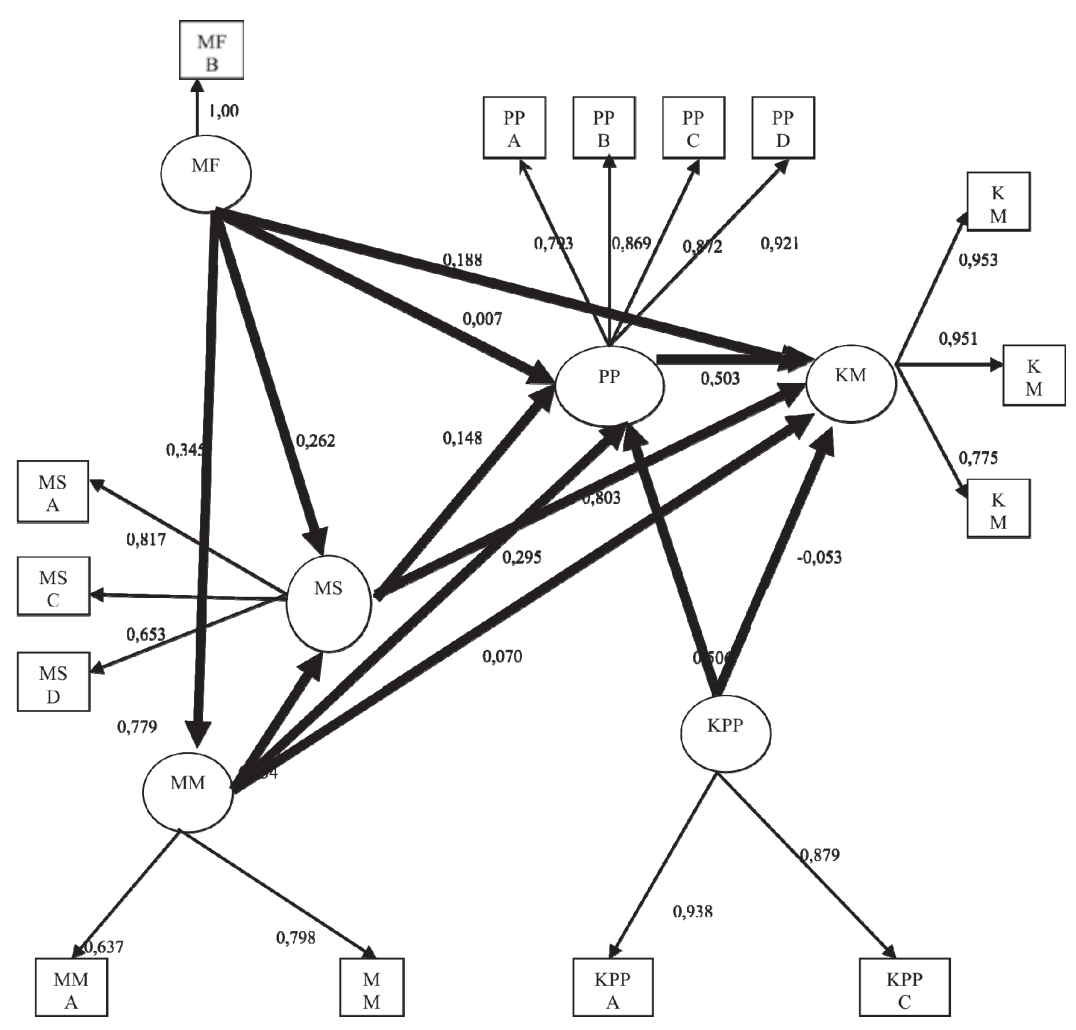

Gambar 2. Model Pemberdayaan Masyarakat Setelah Dilakukan Pengujian Convergent Validity 
factor yang lebih kecil dari 0,60, seperti pada Gambar 2.

Dari pengujian convergent validity 1 sampai dengan 3, dapat disimpulkan bahwa pada intinya indikator untuk masing-masing konstruk pada convergent validity semuanya signifikan, karena mempunyai nilai $t$ statistik lebih besar 1,96 dan loading factor lebih besar dari 0,60 . Hal ini menunjukkan bahwa konstruk modal fisik, modal manusia, modal sosial, kemampuan pelaku pemberdayaan, proses pemberdayaan dan keberdayaan masyarakat adalah valid. Hasil dari penelitian ini adalah bahwa untuk meningkatkan keberdayaan masyarakat sekitar hutan Desa Sumber Rahayu dapat dicapai melalui langkah langkah yang bermula dari:

(1) Modal Fisik. Variabel modal fisik dalam penelitian ini diwujudkan dalam bentuk indikator sarana produksi pertanian, sarana dan prasarana pendidikan, sarana dan prasarana kesehatan, sarana dan prasarana ekonomi, sarana dan prasarana komunikasi, dan sarana dan prasarana transportasi. Hasil pengujian analisis faktor Confirmatory menunjukkan bahwa hanya ada satu indikator yang signifikan dan mempunyai loading factor lebih dari 0,60, yaitu indikator sarana dan prasarana pendidikan (MFB), sementara indikator lainnya mempunyai loading factor di bawah 0,60 .

Confirmatory analysis terhadap modal fisik menunjukkan bahwa sarana dan prasarana pendidikan merupakan pengukur yang representatif modal fisik. Hasil ini menunjukkan bahwa perusahaan memandang bahwa sarana dan prasarana pendidikan dimana tingkat pendidikan yang cenderung mempunyai wawasan yang lebih besar dengan kemandirian untuk mengambil keputusan dapat mendukung keberdayaan masyarakat.

Sarana dan prasarana pendidikan suatu desa dapat merubah tingkat keberanian dalam mengambil keputusan. Perubahan ini akan berdampak juga pada perubahan keberdayaan masyarakat di Desa Sumber Rahayu. Untuk dapat meningkatkan keberdayaannya memerlukan proses pemberdayaan yang didukung oleh modal manusia, selain modal fisik. Melalui proses pemberdayaan, dapat dikembangkan pelatihan untuk masyarakat agar lebih mandiri.
Berdasarkan perubahan tersebut, masyarakat akan melakukan perubahan dalam mengubah budaya ke arah orientasi yang lebih maju. Perubahan ini tidak membatasi cakupan aktivitas dalam pengambilan keputusan saja, tetapi juga meliputi aktivitas yang berkaitan dengan peningkatan kesejahteraan masyarakat. Keberdayaan masyarakat yang didukung modal fisik dicerminkan dengan derajat peningkatan sarana dan prasarana pendidikan secara merata. Dukungan Pemerintah pada peningkatan sarana dan prasarana pendidikan memungkinkan untuk bertambah jika keberdayaan masyarakat suatu desa meningkat. Untuk memudahkan proses pemberdayaan yang lebih cepat yaitu dengan cara meningkatkan modal fisik dan modal manusia. Hal ini diharapkan akan memudahkan komunikasi antara masyarakat, sehingga akan memudahkan aliran informasi yang dapat membuka perubahan kearah yang lebih maju.

Berdasarkan hasil pengujian indikator ditunjukkan bahwa modal fisik sarana produksi pertanian (MFA) tidak digunakan sebagai indikator modal fisik. Hal ini dapat dijelaskan karena sarana produksi pertanian belum sepenuhnya dapat memotivasi masyarakat agar bekerja lebih produktif sesuai dengan pencapaian tujuan masyarakat Desa Sumber Rahayu. Sarana dan prasrana kesehatan masih rendah, sementara sarana dan prasarana komunikasi dan transportasi juga tidak representatif sebagai indikator modal fisik karena masyarakat hanya melakukan komunikasi berbasis pada tular menular informasi, sedangkan komunikasi berbasis teknologi sedikit dilakukan. Komunikasi antarmasyarakat belum sepenuhnya dapat mendorong komitmen masyarakat desa untuk lebih berdaya.

(2) Modal Manusia. Variabel modal manusia dalam penelitian ini semula diukur dengan tiga indikator, yaitu tingkat pendidikan (MMA), tingkat kesehatan (MMB), dan kemampuan berinteraksi antarsesama (MMC). Varibel indikator ini mengacu pada teori yang menjelaskan bahwa modal manusia dapat ditingkatkan melalui tingkat pendidikan, kesehatan dan kemampuan interaksi.

Hasil pengujian analisis faktor confirmatory menunjukkan bahwa dua indikator signifikan 
pada $\mathrm{p}<0,005$, tetapi ada satu indikator yang mempunyai loading faktor kurang dari 0,60 yaitu indikator tingkat kesehatan (MMB), sedangkan indikator yang mempunyai loading factor di atas 0,60 ada dua indikator, yaitu tingkat pendidikan (MMA) dan kemampuan berinteraksi antarsesama (MMC).

Indikator tingkat pendidikan dan kemampuan berinteraksi antarsesama merupakan pengukur yang valid untuk modal manusia. Masyarakat memandang penting upaya-upaya dalam melaksanakan kemampuan berinteraksi yang menghasilkan aktivitas yang dapat mendukung proses pemberdayaan yang akan dikembangkan ke arah keberdayaan masyarakat.

Hasil pengujian indikator ini mendukung pendapat Romer (1990) yang menyatakan bahwa proses modal manusia dapat diperoleh melalui pendidikan dan pengalaman dalam share interpretasi, sebagaimana pendapat Tobing (2005) bahwa modal manusia dapat diperoleh dengan melakukan akumulasi pada stok pengetahuan untuk meningkatkan kemampuan masyarakat dalam melakukan asosiasi (berhubungan) satu sama lain. dan penciptaan bisnis baru (MSE). Sedangkan yang mempunyai loading factor di atas 0,60 ada tiga indikator yaitu jaringan sosial/kerja (MSA), ketaatan terhadap norma (MSC) dan kepedulian terhadap sesama (MSD). Hal ini mengindikasikan bahwa masyarakat di Desa Sumber Rahayu telah mempunyai jaringan sosial/kerja dan dalam aktivitas-aktivitasnya sangat memperhatikan ketaatan terhadap norma dan kepedulian terhadap sesama. Ketika tingkat kepedulian terhadap sesama yang ada dalam masyarakat meningkat, memungkinkan memperkuat budaya dalam meningkatkan keinginan untuk menambah tali persaudaraan yang mengarah pada tujuan bersama untuk kesejahteraan.

Confirmatory analysis konstruk modal sosial menyatakan bahwa jaringan sosial/kerja, ketaatan terhadap norma dan kepedulian terhadap sesama merupakan indikator-indikator yang representatif untuk mengukur modal sosial. Hal ini mendukung konsep Fukuyama (1985) yang menyatakan bahwa modal sosial berkaitan dengan serangkaian nilai dan norma informal yang dimiliki bersama di antara para anggota suatu kelompok yang memungkinkan 
menekankan pada kemampuan yang dianggap relevan dengan kualitas pelaku pemberdayaan. Keterpaduan kemampuan pelaku pemberdayaan dalam meningkatkan keberhasilan pembangunan harus disertai dengan komitmen yang kuat. Keberhasilan pelaku pemberdayaan dapat diwujudkan melalui peningkatan partisipasi aktif masyarakat.

Hasil pengujian analisis faktor confirmatory menunjukkan bahwa ada tiga indikator yang mempunyai loading factor kurang dari 0,60, yaitu indikator akses new brand (CAA), pelayanan superior pada pelanggan (TOB) dan reputasi perusahaan (TOC). Sedangkan indikator yang mempunyai loading factor di atas 0,60 ada tiga indikator. Indikator tersebut adalah cost reduction (CAD), akses financial (CAE), dan kapabilitas network dalam meningkatkan bisnis (CAF).

Confirmatory analysis konstruk kemampuan pelaku pemberdayaan menyatakan bahwa peningkatan pengetahuan/kognitif dan kemampuan ketrampilan/psikomotorik merupakan indikator-indikator yang representatif untuk an pelaku untuk keberhasilan pemberdayaan. Sesuai dengan pendapat Sulistiyani (2004) yang mengemukakan bahwa sikap/afektif lebih bersifat kompleks, dan pada tahap awal lebih sulit dirubah dan dipindahkan dibandingkan pengetahuan dan ketrampilan.

(5) Proses Pemberdayaan. Variabel indikator yang mengukur proses pemberdayaan ada empat yaitu analisis masalah (PPA), perencanaan (PPB), pelaksanaan (PPC) dan evaluasi (PPD).

Hasil pengujian analisis faktor confirmatory menunjukkan bahws semua indikator mempunyai nilai statistik signifikan dan mempunyai loading factor lebih dari 0,60. Variabel indikator yang memberi sumbangan terbesar dalam menjelaskan proses pemberdayaan adalah indikator evaluasi. Variabel indikator yang memberi sumbangan kedua dalam menjelaskan proses pemberdayaan adalah variabel indikator pelaksanaan. Sedangkan variabel indikator yang memberikan sumbangan peringkat terakhir adalah variabel analisis masalah.

Confirmatory analysis konstruk proses pem- 
keputusan masyarakat, tingkat kemandirian, dan kemampuan memanfaatkan usaha untuk masa depan. Variabel indikator ini mengacu pada penelitian terdahulu yang menyatakan bahwa keberdayaan masyarakat meliputi kemandirian (Sulistiyani, 2004), dan masyarakat mampu mengambil keputusan dan mampu menangkap informasi untuk memanfaatkan usaha di masa depan (Slamet, 2003).

Setelah dilakukan pengujian analisis faktor confirmatory, semua indikator signifikan pada $\mathrm{p}<0,005$ dan menunjukkan bahwa semua indikator mempunyai loading factor diatas 0,60 . Hal ini mengindikasikan bahwa masyarakat di Desa Sumber Rahayu telah mempunyai kemampuan untuk mengambil keputusan yang mengarah pada kemandirian masyarakat yang dapat memanfaatkan usaha untuk masa depan. Ketika tingkat kemandirian masyarakat meningkat, memungkinkan memperkuat budaya dalam meningkatkan keinginan untuk menambah kesempatan memanfaatkan peluang yang mengarah pada pengoptimalan partisipasi masyarakat untuk tujuan pembangunan bersama mencapai kesejahteraan.

Confirmatory analysis konstruk keberdayaan masyarakat menyatakan kemampuan mengambil keputusan, kemandirian, dan kemampuan memanfaatkan usaha untuk masa depan merupakan indikator-indikator yang representatif untuk mengukur keberdayaan masyarakat. Hal ini mendukung konsep Pranarka dan Vidhyandika (1996) yang menyatakan bahwa keberdayaan masyarakat berkaitan dengan kemandirian masyarakat.

Hasil pengujian hipótesis dengan Partial Least Square pada model penelitian yang merupakan persamaan struktural hipotesis 1 sampai dengan hipotesis 12 dapat dijelaskan pada Tabel 1.

Dari hasil pengujian hipotesis yang diuji dengan tingkat kesalahan Alpha 0,05, menunjukkan terdapat enam hipotesis yang diterima dan enam hipotesis yang tidak diterima (Tabel 1). Hipotesis 1, 2, 3, 4, 5, dan 6 digunakan untuk menjawab pertanyaan penelitian 1 yaitu apakah kondisi modal fisik, manusia dan sosial mampu mendukung proses pemberdayaan?. Sedangkan hipotesis 7 untuk menjawab pertanyaan penelitian: apakah pelaku pemberdayaan berpenga- ruh terhadap proses pemberdayaan? Dan hipotesis $8,9,10$, 11, dan 12 menjawab pertanyaan penelitian apakah peningkatan keberdayaan dapat dicapai secara langsung atau tidak langsung melalui pengembangan modal fisik, modal manusia, dan modal sosial?

Tabel 1. Hasil Pengujian Hipotesis Penelitian

\begin{tabular}{|c|c|c|c|}
\hline & $\begin{array}{l}\text { Path } \\
\text { Cooef }\end{array}$ & $\begin{array}{c}t- \\
\text { value }\end{array}$ & Keterangan \\
\hline \multicolumn{4}{|l|}{ Modal Fisik } \\
\hline Modal Manusia & 0,345 & 2,574 & ${ }^{*}$ Diterima \\
\hline \multicolumn{4}{|l|}{ Modal Sosial } \\
\hline Modal Fisik & 0,262 & 2,078 & *Diterima \\
\hline Modal manusia & 0,434 & 3,273 & ${ }^{*}$ Diterima \\
\hline \multicolumn{4}{|l|}{$\begin{array}{l}\text { Proses } \\
\text { Pemberdayaan }\end{array}$} \\
\hline Modal Fisik & 0,007 & 0,064 & Tidak Diterima \\
\hline Modal Manusia & 0,295 & 2,258 & *Diterima \\
\hline Modal Sosial & 0,148 & 1,163 & Tidak diterima \\
\hline $\begin{array}{l}\text { Kemampuan Pela- } \\
\text { ku Pemberdayaan }\end{array}$ & 0,506 & 4,458 & ${ }^{*}$ Diterima \\
\hline \multicolumn{4}{|l|}{$\begin{array}{l}\text { Keberdayaan } \\
\text { Masyarakat }\end{array}$} \\
\hline Modal Fisik & 0,188 & 1,326 & Tidak Diterima \\
\hline Modal Manusia & 0,070 & 0,484 & Tidak Diterima \\
\hline Modal Sosial & 0,083 & 0,669 & Tidak Diterima \\
\hline $\begin{array}{l}\text { Proses } \\
\text { Pemberdayaan }\end{array}$ & 0,503 & 3,044 & * Diterima \\
\hline $\begin{array}{l}\text { Kemampuan } \\
\text { Pelaku Pember- } \\
\text { dayaan }\end{array}$ & $-0,053$ & 0,258 & Tidak Diterima \\
\hline
\end{tabular}

Sumber: hasil analisis data

Hasil tersebut bermakna bahwa terdapat langkah-langkah utama yang dapat dilakukan dalam rangka meningkatkan keberdayaan masyarakat: Pertama adalah modal fisik. Untuk dapat meningkatkan pemberdayaan, pengembangan modal fisik harus dilakukan. Peran modal fisik diharapkan bisa mengubah kualitas manusia menjadi lebih berpendidikan dalam meningkatkan kemampuan berinteraksi antar sesama. Masyarakat dapat memanfaatkan usaha di masa depan apabila melakukan analisis yang berkaitan dengan menangkap peluang usaha dengan menitikberatkan pada penting- 
nya peluasan jaringan sosial/kerja. Kedua adalah pengembangan modal manusia. Peran modal manusia menjadi landasan mengembangkan pemberdayaan dan menjadi mediasi peningkatkan keberdayaan masyarakat dari modal fisik. Oleh karena itu, sharing pengetahuan merupakan syarat untuk dapat meningkatkan kreativitas dan inovasi. Masyarakat akan lebih optimal dalam pengembangan pemberdayaan apabila didukung proses peningkatan kualitas manusianya. Peran pelaku pemberdayaan akan meningkatkan kompetensi baik pengetahuan maupun keahliannya untuk dapat menjadi penentu pelaksanaan kegiatan dalam menciptakan masyarakat yang berdaya saing. Ketiga adalah pengembangan pemberdayaan. Untuk menciptakan masyarakat yang berdaya, selain ditentukan oleh kemampuan melakukan evaluasi, dan perencanaan, juga ditentukan oleh kemampuan berinteraksi antarsesama. Keterbukaan antarmasyarakat akan memudahkan akses informasi yang penting dalam melakukan inovasi yang berbeda dengan yang lain, sehingga dapat menciptakan keunggulan. Perlunya menghargai inovasi dan ide-ide baru dalam masyarakat, sebagai faktor pendorong untuk berani mengambil resiko yang bertujuan untuk peningkatan keunggulan di bidang usaha.

Untuk menilai inner model atau model strukturalnya, yaitu ingin melihat hubungan antarkonstruk, salah satu indikator kekuatan prediktif model jalur adalah menguji nilai $R$ square untuk konstruk endogen. R-square digunakan untuk menilai konstruk dependen dalam model structural. $R$-square diinterpretasikan sama seperti analisis regresi berganda yang mengindikasikan jumlah variance dalam konstruk yang dijelaskan oleh model jalur (Chin, 1996). Hasil evaluasi model struktural dengan menggunakan $R$-square seperti pada Tabel 2.
Tabel 2. Nilai R-Square

\begin{tabular}{lc}
\hline \multicolumn{1}{c}{ Variabel } & R-square \\
\hline Modal Fisik & \\
Modal Manusia & 0,089 \\
Modal Sosial & 0,444 \\
Kemampuan Pelaku Pemberdayaan & \\
Proses Pemberdayaan & 0,610 \\
Keberdayaan Masyarakat & 0,424 \\
\hline
\end{tabular}

Sumber: hasil analisis data

Hasil empirik penelitian menunjukkan bahwa nilai $R$-square yang tertinggi adalah proses pemberdayaan sebesar 61,0 persen. Nilai ini mengindikasikan bahwa modal fisik, modal manusia, modal sosial, dan kemampuan pelaku mampu memberikan kontribusi penjelasan proses pemberdayaan sebesar 61,1 persen, sedangkan 38,9 persen dipengaruhi oleh variabel lain. Sementara itu $R$-square pada variabel keberdayaan masyarakat lebih rendah dari $R$-square proses pemberdayaan, yaitu hanya sebesar 42,4 persen. Hal ini menunjukkan bahwa lima variabel yaitu modal fisik, modal manusia, modal sosial, kemampuan pelaku pemberdayaan, dan proses pemberdayaan belum cukup menjelaskan keberdayaan masyarakat.

\section{SIMPULAN}

Penelitian ini memberi kesimpulan terhadap masalah penelitian yang telah diajukan sebelumnya, yaitu: bagaimana proses meningkatkan keberdayaan warga masyarakat melalui proses pemberdayaan yang terwujud dari modal sosial, modal manusia, modal fisik dan kemampuan pelaku. Hal ini akan dapat memberikan solusi yang lebih baik karena dapat menambah penjelasan bahwa proses pemberdayaan ma-

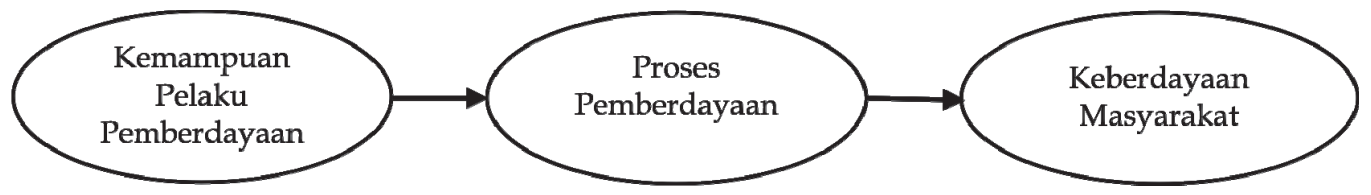

Gambar 3. Pola Pertama Proses Pemberdayaan Masyarakat 
syarakat mutlak diperlukan untuk mencapai keberdayaan masyarakat. Ada dua pola untuk meningkatkan keberdayaan masyarakat. Pola pertama, adalah ada dua konstruk sebagai antesedennya, seperti ditunjukkan pada Gambar 3.

Temuan ini memberikan solusi bahwa peran kemampuan pelaku pemberdayaan akan efektif dapat meningkatkan keberdayaan masyarakat jika masyarakat sebelumnya meningkatkan pemberdayaannya. Pelaku pemberdayaan tidak dapat langsung berpengaruh terhadap keberdayaan masyarakat, tetapi harus dimediasi dengan proses yang mengiringi pemberdayaan. Peningkatan pemberdayaan sebagai penentu keberhasilan pelaku dalam upaya peningkatan keberdayaan masyarakat.

Proses pemberdayaan di Desa Sumber Rahayu berpengaruh secara signifikan terhadap keberdayaan masyarakat. Proses pemberdayaan ini ditandai adanya kemampuan masyarakat dalam membuat analisis masalah, perencanaan, pelaksanaan dan evaluasi suatu program pemberdayaan. Peran pelaku perlu diperbaiki dalam pengetahuan dan ketrampilannya agar dapat memberi dukungan dalam memperlancar keberhasilan pemberdayaan, sehingga dapat meningkatkan kemandirian masyarakat yang berkelanjutan.

Pola kedua, adalah pola jalur bertahap yang dapat dilalui untuk pemberdayaan masyarakat. Peningkatan keberdayaan masyarakat dapat dicapai melalui proses pemberdayaan karena adanya peran modal manusia dan modal fisik. Temuan ini memberikan solusi bahwa modal usaha yang meliputi modak fisik dan modal manusia tidak secara otomatis menghasilkan keberdayaan masyarakat. Pengembangan modal fisik akan menstimulasi pengembangan modal manusia yang akan mendukung proses pemberdayaan yang pada akhirnya akan meningkatkan keberdayaan masyarakat seperti pada Gambar 4.

Untuk dapat meningkatkan keberdayaannya, masyarakat tidak hanya cukup melakukan pengembangan modal fisik saja, tetapi juga harus meningkatkan kualitas sumberdaya manusianya sebagai syarat kesuksesan dalam melakukan pemberdayaan. Dalam era reformasi ini, masyarakat harus mampu dan berani mengambil keputusan untuk melakukan usaha baru untuk masa depan.

Penelitian ini membuktikan bahwa modal manusia berperan memainkan perubahan sumber daya masyarakat untuk meraih kesuksesan proses pemberdayaan. Modal manusia ditandai adanya tingkat pendidikan yang memadai yang diperoleh dari dukungan pengembangan sarana dan prasarana pendidikan sehingga dapat mengembangkan pemberdayaannya dan akan berdampak secara signifikan pada kemandirian masyarakat. Penelitian ini menegaskan bahwa masyarakat dalam meningkatkan pemberdayaannya didasari atas pertimbangan sumber daya yang ada. Untuk dapat menyesuaikan di era reformasi ini, masyarakat harus dapat melakukan perubahan yang lebih kompetitif dengan melakukan peningkatan pendidikan dan keterampilannya untuk menjadi masyarakat yang tajam dalam menangkap peluang yang berorientasi pada masa depan. Temuan ini mendukung penelitian yang dilakukan oleh Fukuyama (1995) tentang hubungan kemampuan masyarakat dengan modal manusia $(h u-$ man capital) dan berimplikasi pada teori yang terkait dengan konsep yang dikembangkan Romer (1990) dimana human capital sebagai anteseden proses pemberdayaan.

Peningkatan keberdayaan masyarakat memerlukan satu paket secara koheren dari perubahan modal fisik yang dibangun berdasarkan kekuatan sarana dan prasarana pendidikan dalam mengembangkan sumber daya manusia dan kemampuan pelaku pemberdayaan dalam

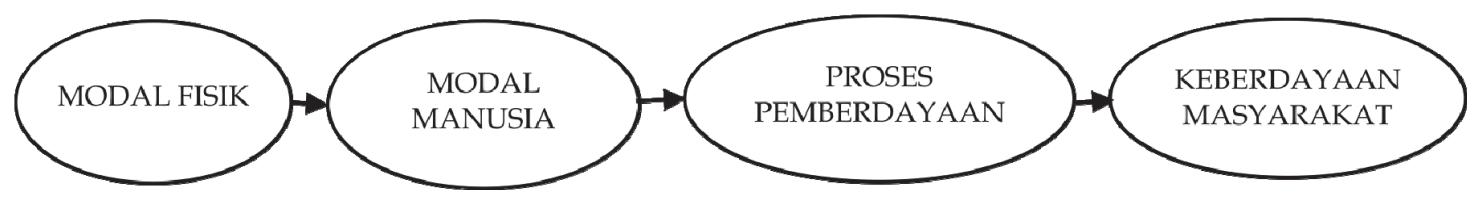

Gambar 4. Pola Kedua Pemberdayaan Masyarakat 
mengembangkan pemberdayaan masyarakat. Hasil ini merupakan kontribusi terhadap aplikasi empirik dari konsep yang dikembangkan oleh Fukuyama (1995) tentang hubungan human capital dan keberdayaan masyarakat. Dan juga mendukung penelitian Sumodiningrat (2000) bahwa keterlibatan fasilitator sebagai pelaku pemberdayaan dalam mengawal proses pemberdayaan merupakan sumber penting sebagai jalur untuk meraih keberdayaan masyarakat. Untuk dapat meningkatkan $R$ square keberdayaan masyarakat, penelitian yang akan datang hendaknya mempertimbangkan variabel lain selain modal fisik, modal manusia, modal sosial, kemampuan pelaku pemberdayaan dan proses pemberdayaan sebagai faktor penentu keberhasilan keberdayaan masyarakat.

\section{DAFTAR PUSTAKA}

Chin,W.W., Marcolin, B.L dan Newsted, P.R. 1996. A Partial Least Squares Latent Variable Modeling Approach for Measuring Interaction Effects: Result from a Monte Carlo Simulation Study and Voice Mail Emotion/Adoption Study. Proceeding of the Seventeenth International Conference on Information System.16_18 December. Cleveland.Ohio.

Fukuyama, 1995. Trust: The Social Virtues and the Creation of Prosperity. Free Press, ISBN 0-02-910976_0

Huseini, M. 1999. Mencermati Misteri Globalisasi: Menata Ulang Strategi Pemasaran Internasional Indonesia Melalui Pendekatan Resource-Based. Depok: Fisip Universitas Indonesia.

Jamasy, O. 2004. Keadilan, Pemberdayaan, E Penanggulangan Kemiskinan. Jakarta Selatan: Blantika.

Kartasasmita, G. 1996. Power and Empowermant: Sebuah Telaah Mengenal Konsep Pemberdayaan Masyarakat. Jakarta: Badan Perencanaan Pembangunan Nasional.

Pranarka dan Vidhyandika, 1996. Pember- dayaan dalam Onny S.P dan AMW. Pranarka (ed). 1996. Pemberdayaan: Konsep, Kebijakan dan Implementasi. Jakarta: Center for Strategic and International Studies (CSIS).

Romer Paul. 1990. Endogenous Technological Change. Journal of Political Economy

Simon, H. 1993. Hutan Jati dan Kemakmuran. Problematika dan Strategi Pemecahannya. Yogyakarta: Aditya Media.

Slamet, M. 2003. Pemberdayaan Masyarakat. dalam Membetuk Pola Perilaku Manusia Pembangunan. Disunting oleh Ida Yustina dan Adjat Sudradjat. Bogor: IPB Press.

Suharto, E. \& Yuliani. 2005. Analisis Jaringan Sosial: Menerapkan Metode Asessmen Cepat dan Partisipatif (MACPA) Pada Lembaga Sosial Lokal di Subang, Jawa Barat: http://www.policy.hu/ suharto/ mak-Indo4.html. Diakses pada 28 Juli 2005.

Sulistiyani, A.T. 2004. Kemitraan dan ModelModel Pemberdayaan. Yogyakarta: Gaya Media.

Sumardjo. 1999. Transformasi Model Penyuluhan Pertanian Menuju Pengembangan Kemandirian Petani: Kasus di Propinsi Jawa Barat. Disertasi Doktor. Bogor: Program Pascasarjana Institut Pertanian Bogor.

Sumodiningrat, G. 2000. Visi dan Misi Pembangunan Pertanian Berbasis Pemberdayaan. Yogyakarta: IDEA.

Syabra, R. 2003. Modal Sosial: Konsep dan aplikasi. Jurnal Masyarakat dan Budaya. Vol.V. N0.1:1-5.

Tobing, E. 2005. Pendidikan dan Pertumbuhan Ekonomi. (Article on-line). Didapat dari http:/ / www-theindone-sian-institute. org/ janeducfile.htm. Internet.

Tjokrowinoto, M. 2001. Pembangunan Dilema dan Tantangan. Yogyakarta: Pustaka Pelajar. 